\title{
PENGARUH PERPUTARAN KAS,PERPUTARAN PIUTANG, PERPUTARAN PERSEDIAAN TERHADAP PROFITABILITAS PADA SUPERMARKET DI TIMOR LESTE
}

\author{
Matilde Amaral Canizio \\ Program Pascasarjana Universitas Udayana (Unud), Bali Indonesia \\ E-mail: caniziomatilde@yahoo.com,
}

\begin{abstract}
ABSTRAK
Tujuan penelitian ini adalah untuk mengetahui pengaruh perputaran kas, perputaran piutang, perputaran persediaan terhadap profitabilitas perusahaan. Sampel penelitian adalah dua supermarket di Timor Leste. Penelitian ini menggunakan data sekunder yang diperoleh dari laporan keuangan bulanan supermarket dari periode 2008 sampai dengan 2012. Teknik Analisis yang digunakan adalah analisis Regresi Linier Berganda. Berdasarkan hasil analisis dapat ditemukan bahwa perputaran kas terdapat pengaruh tidak signifikan terhadap profitabilitas pada supermarket Leader dan Lita store. Sedangkan perputaran piutang dan perputaran persediaan berpengaruh positif terhadap profitabilitas pada supermarket Leader dan Lita store.
\end{abstract}

Kata Kunci : Perputaran Kas, Perputaran Piutang, Perputaran Persediaan dan Profitabilitas.

\begin{abstract}
The purpose of the study is to examine and demonstrate empirically the effect of cash turnover, receivable turnover, and inventory turnover on profitability of compnies. The date used in this study is a secondary date obtained from the compnay's monthly financial reports during the period 2008 to 2012. Samples used are 2 Supermarket. Statistical analysis used is multiple linear regression analysis. Based on the result of analysis it can be concluded that in the cash turnover there are no significant effects on profitability in the supermarkets Leader and Lita Store. While the receivables turnover and inventory turnover have a positive effect on the profitability of the supermarket Leader and Lita Store.
\end{abstract}

Keywords : Cash turnover, Receivables Turnover, Inventory Turnover on Profitability. 


\section{PENDAHULUAN}

Tujuan supermarket pada umumnya adalah untuk melakukan berbagai kegiatan ekonomi hingga mencapai tujuan yang telah ditentukan dan berjalan secara terus menerus. Untuk mendukung kegiatan-kegiatan itu tentunya supermarket membutuhkan dana baik untuk membiayai kegiatan operasional maupun untuk membiayai investasi jangka panjang, jadi diharapkan agar dalam pengelolaan keuangan dilakukan dengan professional yaitu dengan memperhatikan manajemen kas, piutang dan persediaan demi mencapai profitabilitas supermarket.

Menurut Munawir (2007:33), menjelaskan bahwa “ profitabilitas menunjukkan kemampuan perusahaan untuk menghasilkan laba selama periode tertentu. Kasmir (2012:196) mengungkapkan “ rasio profitabilitas merupakan rasio untuk menilai kemampuan perusahaan dalam mencari keuntungan.” Sejalan dengan hal tersebut menurut Sutrisno (2009:222) rasio keuntungan digunakan untuk mengukur seberapa besar tingkat keuntungan yang dapat diperoleh perusahaan, dimana semakin besar tingkat keuntungan menunjukkan semakin baik manajemen dalam mengelola perusahaan.

Menuh (2008) menyatakan bahwa perputaran kas merupakan periode berputarnya kas yang dimulai pada saat kas dinvestasikan dalam komponen modal kerja sampai saat kembali menjadi kas, kas sebagai unsure modal kerja yang paling tinggi likuiditasnya. Menurut Riyanto (2001) semakin tinggi perputaran kas akan semakin baik, karna ini berarti semakin tinggi efisiensi pengunaan kasnya dan keuntungan yang diperoleh akan semakin besar. 
Berdasarkan pendapat para ahli tersebut maka, untuk mengetahui tingkat efektifitas dari sebuah perusahaan dapat diukur dari tingkat perputarannya. Dalam penelitian ini variabel yang digunakan sebagai variabel bebas adalah perputaran kas, perputaran piutang, perputaran persediaan sedangkan variabel terikat adalah profitabilitas, dimana profitabilitas dapat diukur dengan mengunakan Return on Assets (ROA).

Beberapa penelitian telah dilakukan untuk menganalisis faktor-faktor yang dapat mempengaruhi profitabilitas yang hasil penelitiannya ada yang sejalan dan ada yang bertentangan. Penelitian diantaranya yang dilakukan oleh putra (2012) menunjukan bahwa perputaran kas, perputaran persediaan berpengaruh positif signifikan terhadap profitabilitas. Penelitian tersebut diperkuat oleh Raheman dan Nasri (2007) dimana perputaran persediaan dan perputaran kas berpengaruh positif signifikan terhadap profitabilitas. Hasil penelitian berbeda juga didapatkan oleh Teruel dan Solano (2007) yang menyimpulkan bahwa perputaran piutang, perputaran persediaan mempunyai pengaruh yang negative signifikan terhadap profitabilitas.

Penelitian yang dilakukan oleh Tri Siswantini (2006) mengemukakan bahwa perputaran kas berpengaruh negative terhadap profitabilitas, maksudnya adalah dengan adanya penambahan perputaran kas akan memberikan penurunan terhadap profitabilitas sedangkan untuk perputaran piutang dan perputaran persediaan memberikan pengaruh positif terhadap profitabilitas. 
Tujuan penelitian ini untuk mengkaji dan menganalisis pengaruh perputaran kas, perputaran piutang, perputaran persediaan terhadap profitabilitas karna dari hasil penelitian terdahulu masih saling bertentangan.

\section{KAJIAN PUSTAKA}

Profitabilitas menurut Wiagustini (2010:76) profitabilitas adalah menunjukkan kemampuan perusahaan memperoleh laba atau ukuran efktifitas pengelolaan manajemen perusahaan. Kemampuan memperoleh laba bias diukur dari modal sendiri maupun dari seluruh dana yang diinvestasikan ke dalam perusahaan (Wiagustini,2010:77). Brigham dan Dave (2010) mengemukakan bahwa profitabilitas adalah hasil bersih dari serangkaian kebijakan dan keputusan. Pengertian Modal kerja menurut Wiagustini (2010) dikemukakan dalam 3 (tiga) konsep yaitu:

\section{Konsep kuantitatif}

Konsep didasarkan pada kuantitas dana yang tertanam dalam masing-masing aktiva lancer saja, yang artinya aktiva ini merupakan aktiva yang sekali berputar dan akan kembali dalam bentu semula atau aktiva dengan jumlah dana yang terdapat didalamnya akan dapat bebas lagi dalam jangka waktu yang pendek. Dengan demikian modal kerja menurut konsep ini adalah keseluruhan dari jumlah aktiva lancer yang sering disebut modal kerja bruto (gross working capital)

2. Konsep kualitatif

Pengertian modal kerja dalam konsep ini adalah sebagian dari aktiva lancer yang benar-benar dapat digunakan untuk membiayai operasi perusahaan tanpa 
mengagnggu likuiditasnya yaitu merupakan kelebihan aktiva lancer diatas utang lancer.

3. Konsep fungsional

Pengertian dalam konsep ini didasarkan pada fungsi dana dalam menghasilkan pendapatan yang sering digunakan diperusahaan adalah untuk menghasilkan pendapatan yang sering disebut Current Income. Serta future income yang artinya dana yang tidak secara keseluruhan digunakan untuk menghasilkan pendapatan selama periode tersebut tetapi digunakan untuk periode berikutnya.

Wiagustini (2010) mengungkapkan bahwa unsur-unsur modal kerja yang utama adalah sebagai berikut.

1. Kas (uang tunai)

Kas adalah salah satu unsure modal kerja yang paling tinggi tingkat likuiditasnya. Makin besar jumlah kas yang ada didalam perusahaan berarti semakin tinggi tingkat likuiditasnya. Hal ini berarti bahwa perusahaan mempunyai risiko yang lebih kecil untuk dapat memenuhi kewajiban finansialnya. Tetapi ini tidak berarti bahwa perusahaan harus berusaha untuk mempertahankan persediaan kas yang sangat besar, karna semakin besar kas berarti semakin banyak uang yang menganggur sehingga dapat memperkecil profitabilitas.

2. Piutang

Penjualan kredit tidak segera dapat menghasilkan kas tetapi menimbulkan piutang langanan, kemudian pada hari jatuh tempo terjadi aliran kas masuk yang berasal dari pengumpulan piutang tersebut. Dnegan demikian piutang merupakan elemen modal kerja yang selalu dalam keadaan berputar secara terus menerus dan rantai 
Matilde Amaral Canizio. Pengaruh Perputaran Kas, Perputaran Piutang, Perputaran...

berputaran modal kerja yaitu kas menjadi inventori pada saat perusahaan melakukan pembelian dan inventori berubah menjadi piutang saat perusahaan melakukan penjualan kredit, kemudian piutang akan menjadi kas pada saat telah jatuh tempo.

3. Persediaan

Persediaan atau Inventory adalah bahan atau barang-barang yang pada saat akan dijual kembali oleh perusahaan, tanpa atau setelah mengalami pengolahan. Oleh karena itu, persediaan merupakan suatu unsure yang penting dalam usaha mencapai tingkat penjualan yang dikehendaki.

\section{Pengaruh tingkat perputaran kas terhadap profitabilitas}

Menurut Kasmir (2011:140) rasio perputaran kas (cash turn over) berfungsi untuk mengukur tingkat kecukupan modal kerja perusahaan yang dibutuhkan untuk membayar tagihan dan membiayai penjualan. Perputaran kas merupakan perbandingan antara penjualan dengan jumlah kas rata-rata. Perputaran kas menunjukan kemampuan kas dalam mengahsilkan pendapatan sehingga dapat dilihat berapa kali uang kas berputar dalam satu periode tertentu. Semakin tinggi perputaran kas akan semakin baik profitabilitasnya.

\section{Pengaruh tingkat perputaran kas terhadap profitabilitas}

Menurut Kasmir (2011:140) rasio perputaran kas (cash turn Over) berfungsi untuk mengukur tingkat kecukupan modal kerja perusahaan yang dibutuhkan untuk membayar tagihan dan membiayai penjualan. Perputaran kas merupakan perbandingan antara penjualan dengan jumlah kas rata-rata. Perputaran kas menunjukkan kemampuan kas dalam menghasilkan pendapatan 
sehingga dapat dilihat berapa kali uang kas berputar dalam satu periode tertentu. Semakin tinggi perputaran kas ini akan semakin baik profitabilitasnya.

Rahma (2011) menyatakan bahwa perputaran kas menunjukkan kemampuan kas dalam menghasilkan pendapatan, sehingga dapat dilihat berapa kali uang kas berputar dalam satu periode tertentu. Semakin tinggi perputaran kas ini akan semakin baik, ini berarti semakin tinggi efisiensi penggunaan kasnya dan keuntungan yang diperoleh akan semakin besar (Riyanto,2001). Hal ini sejalan dengan hasil penelitian Rahma (2011), Putra (2012), Raheman dan Nasri (2007), Teruel dan Solano (2007) yang menyatakan bahwa tingkat perputaran kas berpengaruh terhadap profitabilitas.

\section{Pengaruh Tingkat perputaran piutang terhadap profitabilitas}

Piutang muncul karna perusahaan melakukan penjualan secara kredit untuk meningkatkan volume usahanya. Riyanto (2001:90) menyatakan perputaran piutang menunjukana periode terikatnya modal kerja dalam piutang dimana semakin cepat periode berputarnya menunjukan semakin cepat perusahaan mendapatkan keuntungan dari penjualan kredit tersebut, sehingga profitabilitas perusahaan juga ikut meningkat. Hal ini didukung hasil penelitian dari Putra (2010), Wijaya (2012), Sanotso dan Nur (2008) yang menyatakan bahwa tingkat berputaran piutang berpengaruh terhadap profitabilitas.

\section{Pengaruh tingkat perputaran persediaan terhadap profitabilitas}

Pengelolaan persediaan merupakan suatu pekerjaan yang sulit, dimana kesalahan dalam menentukan tingkat persediaan dapat berakibat fatal. RaharjaPutra (2009) menyatakan bahwa semakin tinggi tingkat peputaran 
persediaan, kemungkinan semakin besar perusahaan akan memperoleh keuntungan, begitu pula sebaliknya, Jika tingkat perputaran persediaannya rendah maka kemungkinan semakin kecil perusahaan akan memperoleh keuntungan. Sedangkan Munawir (2004) menyatakan bahwa semakin tinggi tingkat perputaran persediaan akan memperkecil risiko terhadap kerugian yang disebabkan karna penurunan harga atau karna perubahan selera konsumen, disamping itu akan menghemat ongkos penyimpanan dan pemeliharaan terhadap persediaan tersebut. Hal ini didukung oleh hasil penelitian Lazaridis dan Tryfonidis (2006(, Raheman dan nasri (2007) yang menyatakan bahwa tingkat perputaran persediaan berpengaruh terhadap profitabilitas.

\section{KERANGKA BERPIKIR, KONSEPTUAL DAN HIPOTESIS PENELITIAN}

\section{Kerangka Berpikir dan Konseptual}

Profitabilitas perusahaan dipengaruhi oleh banyak faktor. Modal kerja merupakan salah satu faktor yang mempengaruhi profitabilitas perusahaan. Manajemen modal kerja yang baik ditunjukkan oleh pengaruh positif dari kebijakan-kebijakan modal terhadap profitabilitas perusahaan. Berdasarkan kajian teori/konsep tentang profitabilitas dan kebijakan modal kerja, serta beberapa riset / empiris diketahui ada beberapa kebijakan modal kerja yang berpengaruh terhadap profitabilitas. Manajemen modal kerja yang baik ditunjukkan dengan adanya kontribusi yang seimbang dari kebijakan-kebijakan modal kerja terhadap profitabilitas sehingga memaksimalkan profitabilitas Perusahaan.

Perputaran kas mencerminkan efektivitas modal yang dapat mempengaruhi profitabilitas perusahaan. Semakin tinggi siklus perputaran kas 
maka semakin tinggi efisien penggunaan kas perusahaan, dimana mencerminkan kemampuan kas menghasilkan penjualan semakin tinggi, sehingga dapat meningkatkan profitabilitas, karena dana yang menggangur pada kas semakin kecil. Efisiensi penggunaan kas perusahaan diharapkan dapat meningkatkan profitabilitas perusahaan.

Penelitian ini mengkaji pengaruh perputaran Kas, perputaran Piutang dan perputaran persediaan terhadap profitabilitas perusahaan. Kerangka konsep penelitian ini disajikan pada Gambar sebagai berikut:

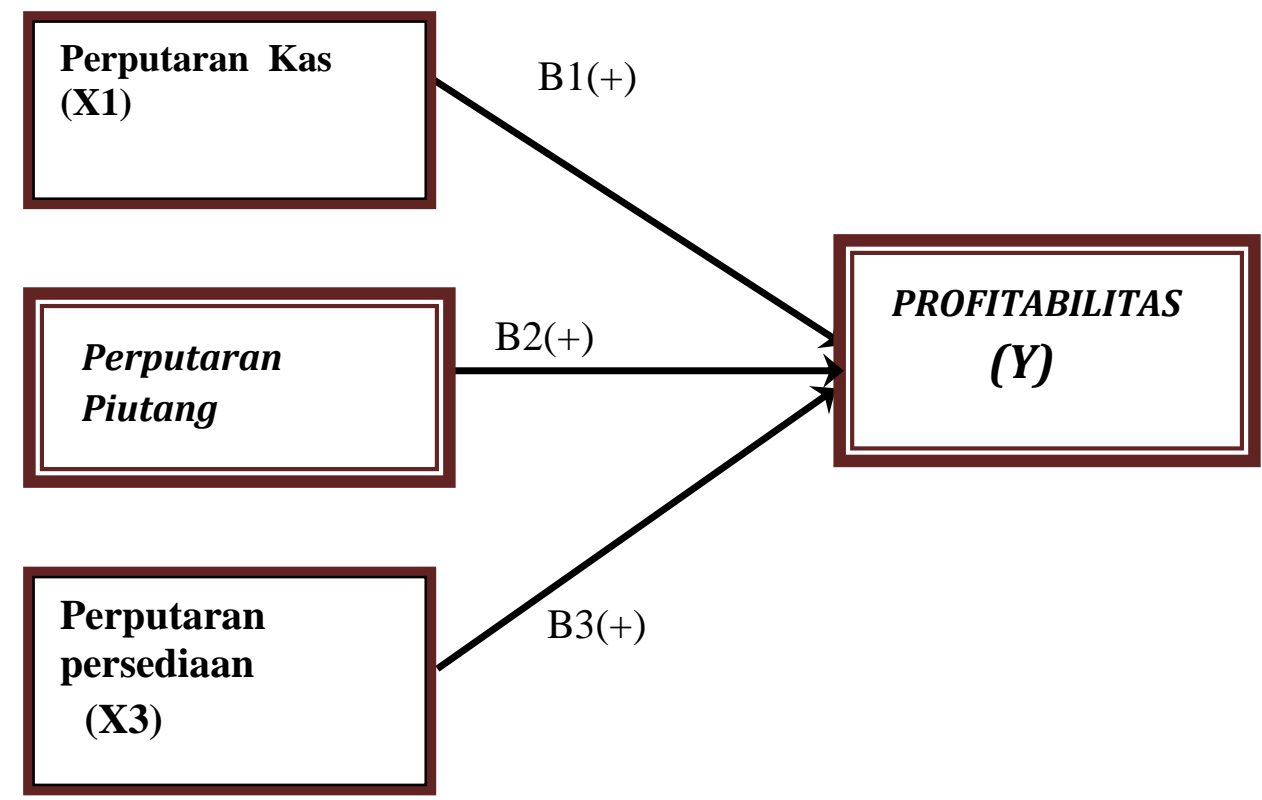

\section{Gambar 1 : Kerangka Konsep Pengaruh Perputaran Kas, Perputaran Piutang, Perputaran persediaan terhadap Profitabilitas}

\section{Hipotesis Penelitian}

Perputaran kas menunjukkan kemampuan kas dalam menghasilkan pendapatan sehingga dapat dilihat berapa kali uang kas berputar dalam satu 
periode tertentu. Semakin tinggi perputaran kas ini akan semakin baik. Karena ini berarti semakin tinggi efisiensi penggunaan kasnya dan keuntungan yang diperoleh akan semakin besar (Wiagustini, 2010). Bhayani (2004) menemukan perputaran kas berpengaruh positip terhadap profitabilitas. Hal yang sama juga ditemukan Anna (2011) dan Muhamad et.al (2010). dimana perputaran kas berpengaruh positif terhadap profitabilitas di perusahaan yang terdaftar di Pasar Modal Malaysia.

Selanjutnya meningkatnya perputaran kas yang menunjukkan efisiensi penggunaan kas di dalam perusahaan dapat meningkatkan profitabilitas, yang selanjutnya dapat meningkatkan permintaan saham, sehingga harga saham naik dan nilai perusahaan naik. Hal tersebut ditemukan oleh Gamze et.al (2012), yang menunjukkan bahwa perputaran kas berpengaruh positif terhadap nilai perusahaan di Pasar Modal Turki. Berdasarkan teori dan empiris yang telah diuraikan dapat dirumuskan hipotesis sebagai berikut:

B1 : Perputaran Kas berpengaruh Positif Signifikan terhadap profitabilitas

Penelitian yang dilakukan oleh Tri Siswantini (2006) mengemukakan bahwa perputaran piutang dan perputaran persediaan memberikan pengaruh positif terhadap profitabilitas, artinya dari kedua variabel itu adanya penambahan perputaran akan memberikan panambahan terhadap profitabilitas. Berdasarkan teori dan empiris yang telah diuraikan dapat dirumuskan hipotesis sebagai berikut: B2 : Perputaran Piutang berpengaruh Positif Signifikan terhadap Profitabilitas B3 :Perputaran persediaan berpengaruh positif Signifikan terhadap profitabilitas. 


\section{METODE PENELITIAN}

Penelitian ini merupakan penelitian kausalitas yaitu hubungan sebab akibat yang mengkaji tentang pengaruh efektifitas pengunaan perputaran kas, perputaran piutang, perputaran persediaan terhadap profitabilitas pada supermarket Leader dan Lita Store. Data yang digunakan dalam penelitian ini adalah laporan keuangan bulanan dari tahun 2008-2012 yang terdiri dari laporan rugi-laba dan laporan neraca. Jumlah supermarket yang memenuhi ada dua supermarket yang diambil sebagai sampel.

Teknik analisis yang digunakan adalah analisis regresi leaner berganda digunakan untuk mengetahui pengaruh variabel bebas (perputaran kas, perputaran piutang, perputaran persediaan) terhadap variabel terikat (profitabilitas). Analisis regresi adalah suatu analisis yang digunakan untuk menunjukkan hubungan matematis antara variable bebas dan variabel terikat.

\section{HASIL DAN PEMBAHASAN}

\section{Deskripsi Variabel Penelitian}

Variabel yang dioperasikan dalam penelitian ini terdiri dari Variabel bebas, dan varaibel terikat. Varaibel bebas adalah perputaran kas (x1), perputaran piutan (x2), perputaran persediaan (x3) dan variable terikat adalah profitabilitas (y).

Masing-masing variable dapat kita lihat pada tebel 5.1 sebagai berikut: 
Tabel 1 Deskripsi variabel Penelitian

\begin{tabular}{lrllll}
\hline \multicolumn{1}{c}{ Variabel } & N & Minimum & Maximum & Mean & Std.Deviation \\
\hline Profitabilitas & 120 & 0,01 & 2,86 & 0,74 & 0,69 \\
Perputaran kas (x1) & 120 & 0,05 & 47,30 & 3,01 & 5,36 \\
$\begin{array}{l}\text { Perputaran piutang } \\
\text { (x2) }\end{array}$ & 120 & 3,27 & 17,96 & 5,90 & 2,89 \\
$\begin{array}{l}\text { Perputaran } \\
\text { persediaan (x3) }\end{array}$ & 120 & 0,02 & 0,92 & 0,31 & 0,19 \\
\hline
\end{tabular}

Berdasarkan Tabel 1 enunjukkan bahwa jumlah pengamatan dalam penelitian ini sebanyak 120 (hasil perkalian periode penelitian sebanyak 60 periode pengamatan). dengan jumlah sampel sebanyak 2. Profitabilitas terendah $0.01 \%$ dan profitabilitas tertinggi $2.86 \%$. Berdasarkan data tersebut dapat diketahui bahwa profitabilitas secara rata-rata mengalami perubahan sebesar 0.74\%. Standar deviasi profitabilitas sebesar 0.69\%. Dengan tingginya simpangan data menunjukkan tingginya fluktuasi data variabel profitabilitas selama periode pengamatan.

Nilai perputaran kas memiliki rata-rata sebesar 3,01 selama tahun 2008 sampai dengan 2012, dengan nilai maximum 47.39 dan minimum sebesar 0.05. Standar deviasi perputaran kas sebesar 5.36 lebih besar dibandingkan nilai mean sebesar 3.01. Dengan besarnya simpangan data menujukkan tingginya fluktuasi data variabel perputaran kas.

Nilai rata-rata perputaran piutang yang dimilki sebesar 5.90 menunjukkan kemampuan perusahaan dalam mengelola piutangnya selama tahun 2008 sampai dengan 2012, dengan nilai maksimum sebesar 17.96 dan minimum sebesar 3.27. 
Standar deviasi perputaran piutang sebesar 2.89 lebih kecil dibandingkan nilai mean sebesar 5.90. Dengan kecilnya simpangan data, menunjukkan rendahnya fluktuasi variabel perputaran piutang.

Perputaran persediaan yang memiliki rata-rata hitung sebesar 0,31 selama tahun 2008 sampai dengan 2012, dengan nialai maximum 0.92 dan minimum sebesar 0.02. Standar deviasi sebesar 0.19 lebih kecil jika dibandingkan nilai mean sebesar 0.31. Dengan kecilnya simpangan data menunjukkan rendahnya fluktuasi data variabel perputaran persediaan.

\section{Pengujian Asumsi Klasik}

Teknik analisis regresi memerlukan adanya pengujian dengan mempertimbangkan kemungkinan adanya penyimpangan terhadap asumsi klasik. Jika masih terdapat penyimpangan asumsi klasik selanjutnya akan dilakukan revisi terhadap data penelitian maupun model regresi. Pengujian penyimpangan asumsi klasik yang terdiri atas gejala normalitas, autokorelasi, multikolinearitas, dan heterokedastisitas. Pengujian-pengujian tersebut dapat diuraikan sebagai berikut:

\section{Hasil Uji Normalitas}

Uji Normalitas dalam penelitian ini mengunakan diagram P-P Plot seperti pada Gambar 1:

Dependent Variabel : Profitabilitas (Y) 


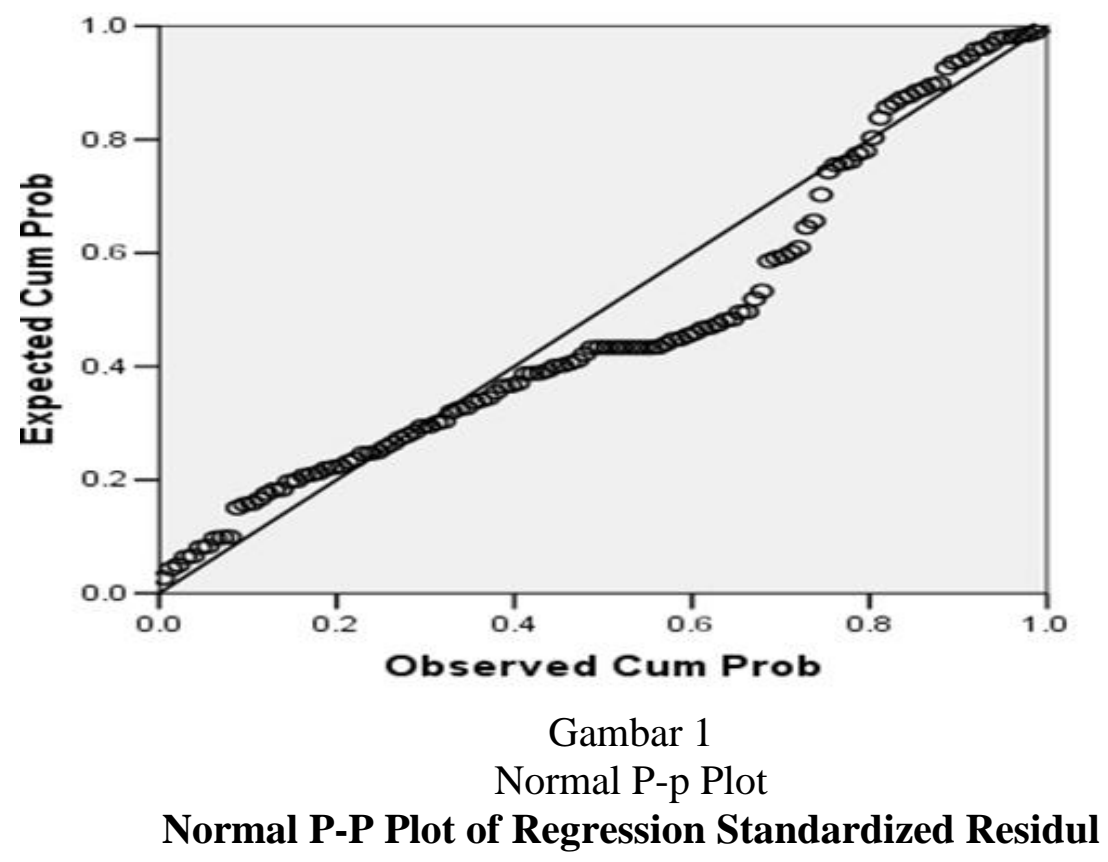

Berdasarkan Gambar 1 dapat dilihat bahwa sebaran data sudah mendekati garis diagonal sehingga dapat disimpulkan data normal.

\section{Hasil Uji Autokorelasi}

Uji autokorelasi bertujuan untuk menguji apakah model regresi linear ada korelasi antara kesalahan penggangu pada periode t-1 (sebelumnya). Menurut Ghozali, (2006) model regresi yang baik adalah regresi yang bebas dari autokorelasi. Uji Autokorelasi dilakukan dengan mengunakan nilai Durbin Watson (DW). Data dikatakan tidak Autokorelasi jika nilai Durbin Watson hitung terletak antara DU dan 4-DU berdasarkan tabel DW dengan alpha 0,05\% dengan jumlah data $(\mathrm{N})=120$ dan jumlah variable $(\mathrm{k})=4$ menghasilkan nilai DL sebesar 1,65, dan DU sebesar 1.75. Nilai 4-DU $=4-1,75=2,25$. Berdasarkan analisis regresi pada Lampiran 2, didapat nilai DW hitung sebesar 2,031. Nilai DW hitung 
sebesasr 2,031 terletak antara DU dan 4- DU sehingga dapat disimpulkan data tidak mengandung autokorelasi.

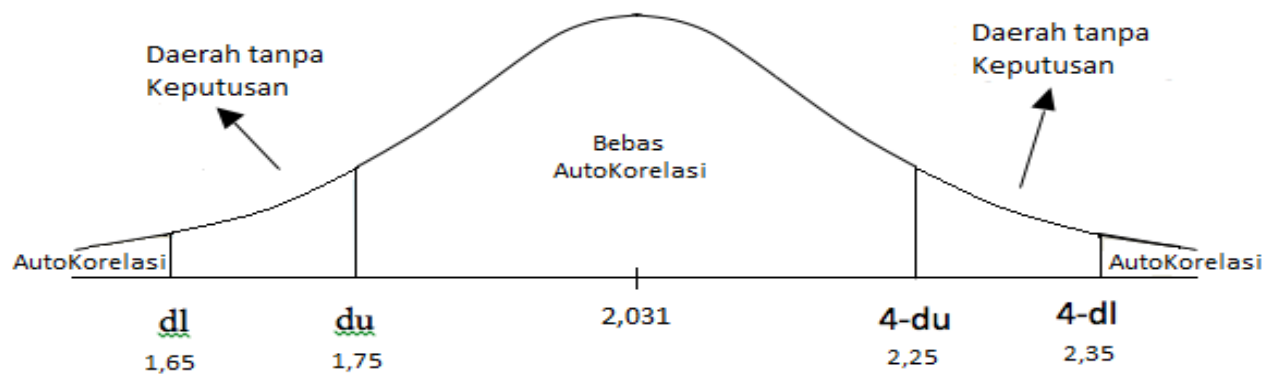

Gambar 2

Pengujian Autokorelasi

Pada Gambar 2 terlihat bahwa nilai DW hitung sebesar 2,031 jatuh pada daerah bebas autokorelasi sehingga dapat disimpulkan bahwa data sudah bebas autokorelasi

\section{Uji Multikolinearitas}

Uji multikolinearitas digunakan untuk mengetahui ada atau tidaknya penyimpangan asumsi klasik multikonearitas, yaitu adanya hubungan linear antar model regresi adalah tidak adanya multikolinearitas (Wiyono,211). Menurut Suliyanto (2011), pada umumnya jika VIF tidak lebih dari 10 maka model dinyatakan tidak terdapat gejala multikolinearitas. Untuk mengetahui terjadi tidaknya multikolinearitas dapat dilihat dari nilai VIF yang terdapat pada masingmasing variabel bebas.

Tabel 2 
Matilde Amaral Canizio. Pengaruh Perputaran Kas, Perputaran Piutang, Perputaran...

\begin{tabular}{|l|l|l|l|}
\hline \multicolumn{1}{|c|}{ Variabel } & \multicolumn{1}{|c|}{ Tolerance } & \multicolumn{1}{c|}{ VIF } & Keterangan \\
\hline Berputaran Kas & 0.812 & 1.231 & Bebas Multikolineritas \\
Berputaran Piutang & 0.779 & 1.284 & Bebas Multikolineritas \\
Berputaran & 0.795 & 1.258 & Bebas Multikolineritas \\
Persediaan & & & \\
\hline
\end{tabular}

Berdasarkan Tabel 2, diperoleh bahwa semua variabel bebas memiliki nilai Tolerance lebih besar dari 0,1 dan nilai VIF jauh di bawah angka 10. Dengan demikian dalam model ini tidak ada masalah multikolinieritas.

\section{Uji Heteroskedastisitas}

Uji heteroskedastisitas bertujuan untuk mengamati Scatterplot di mana sumbu horizontal menggambarkan nilai Predicted Standardized, sumbu vertikal menggambarkan nilai residual Studentized. Jika scatterplot membentuk pola tertentu, menunjukkan adanya masalah heteroskedastisitas pada model regresi yang dibentuk. jika scatterplot menyebar secara acak menunjukkan tidak terjadinya masalah heteroskedastisitas pada model regresi yang bentuk (Suliyanto,2011).

\section{Dependent Variabel : Profitabilitas (Y)}

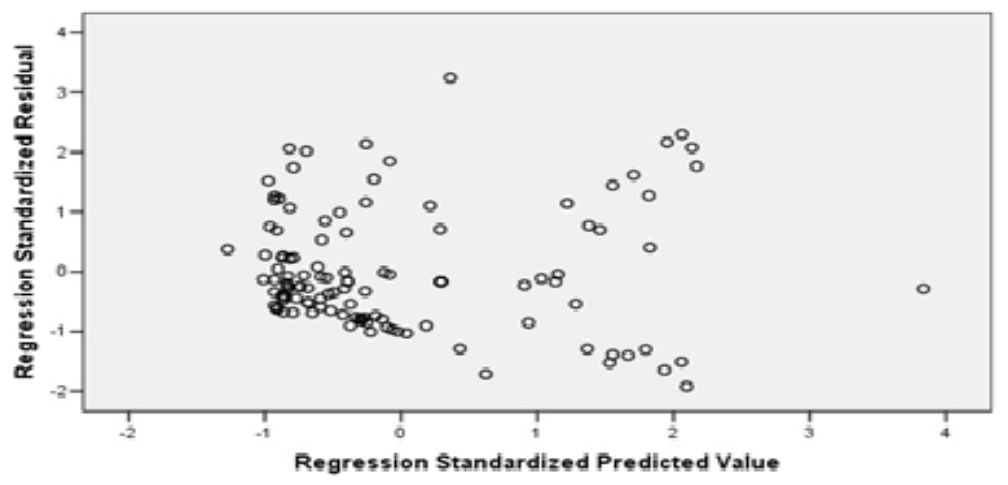

Gambar 5.3

Scatter Plot 
Berdasarkan pada .3 scatterplot terlihat bahwa sebaran plot titik-titk pada diagram sudah terpencar atau tidak membentuk pola pada sumbu Regresion Studentized Residual. Oleh karena itu maka berdasarkan uji heteroskedastisitas dengan menggunakan model regresi yang terbentuk dinyatakan data tidak mengandung heteroskedastisitas.

\section{Pengujian Hipotesis}

Hasil uji pengaruh langsung variabel perputaran piutang, perputaran kas dan perputaran persediaan terhadap profitabilitas dapat dilihat pada Tabel 5.4 berikut ini:

Tabel 3

Output Hasil Regresi Pengaruh Variabel Perputaran Kas, Perputaran Piutang Dan Perputaran Persediaan Terhadap Profitabilitas

\begin{tabular}{|c|c|c|c|c|c|c|c|}
\hline \multirow[t]{2}{*}{ Model } & \multicolumn{2}{|c|}{$\begin{array}{l}\text { Unstandardized } \\
\text { Cefficients }\end{array}$} & \multirow{2}{*}{$\begin{array}{l}\text { Standardized } \\
\text { Cefficients } \\
\text { Beta }\end{array}$} & \multirow[t]{2}{*}{$\mathbf{T}$} & \multirow[t]{2}{*}{ Sig } & \multicolumn{2}{|c|}{$\begin{array}{l}\text { Collinearty } \\
\text { Statistik }\end{array}$} \\
\hline & B & St.Eror & & & & Tolerence & VIF \\
\hline Constanta & -184 & .137 & & -1.342 & .182 & & \\
\hline $\begin{array}{l}\text { Perputaran } \\
\text { Kas X1 }\end{array}$ & .003 & .011 & .025 & .303 & .762 & .812 & 1.231 \\
\hline $\begin{array}{l}\text { Perputaran } \\
\text { Piutang X2 }\end{array}$ & .120 & .020 & .508 & 5.939 & .000 & .779 & 1.284 \\
\hline $\begin{array}{l}\text { Perputaran } \\
\text { Persediaan X3 }\end{array}$ & .637 & .304 & .177 & 2.092 & .039 & .795 & 1.258 \\
\hline
\end{tabular}

a.Dependent variabel Profitabilitas

Berdasarkan hasil analisis yang disajikan pada Tabel 5.3, dapat dibuat persamaan regresi dari model yang diteliti. Bentuk umum persamaan regresi linear berganda adalah 
$\mathrm{Y}=\mathrm{bo}+\mathrm{b} 1 \mathrm{x} 1+\mathrm{b} 2 \times 2+\mathrm{b} 3 \times 3+\mathrm{ei}$

Secara lengkap, hasil pelaporan hasil analisis regresinya adalah sebagai berikut:

$$
\begin{array}{lcccc}
\mathrm{Y} & =-0,184 & +0,003 \times 1 & +0.120 \times 2 & +0,637 \times 3 \\
\mathrm{~B} & =0,025 & 0,508 & 0,177 & \\
\mathrm{Se} & =0,137 & 0,011 & 0,020 & 0,304 \\
\mathrm{t} & =-1,342 & 0,303 & 5,939 & 2,092 \\
\text { sig } & =0,182 & 0,762 & 0,000 & 0,039
\end{array}
$$

R square $=0,340, \mathrm{~F}$ hitung $=19,918$, Sig. uji F: 0,000

Berdasarkan hasil analisis regresi yang disajikan Tabel 3 didapat nilai $\mathrm{F}$ hitung sebesar 19,918 dengan signifikansi sebesar 0,000. Karena nilai signifikansi uji $\mathrm{F}$ sebesar $0,000<0,005$ maka dapat disimpulkan bahwa secara serempak (simultan) variabel perputaran kas, perputaran piutang dan perputaran persediaan berpengaruh signifikan terhadap profitabiltas.

Pengujian Hipotesis dilakukan untuk masing-masing pengaruh variabel bebas seperti berikut ini:

1) Pengaruh Perputaran Kas terhadap Profitabilitas

Berdasarkan analisis didapat nilai koefisien regresi sebesar 0,025 dengan arah positif namun nilai signifikansi uji t variabel perputaran kas sebesar 0,762 , karena nilai signifikansi uji t lebih besar dari 0,05 maka hipotesis yang pertama ditolak. Koefisien regresi memiliki arah positif Jadi perputaran kas berpengaruh positif namun tidak signifikan terhadap profitabilitas.

2) Pengaruh Perputaran piutang terhadap Profitabilitas 
Berdasarkan analisis didapat koefisien regresi sebesar 0,508 dengan arah positif dan nilai signifikansi uji t variabel perputaran Piutang sebesar 0,000 , karena nilai signifikansi uji t lebih kecil dari 0,05 maka hipotesis penelitian yang ke dua diterima Jadi terdapat pengaruh positif yang signifikan variabel perputaran Piutang terhadap profitabilitas.

c) Pengaruh Perputaran Persediaan terhadap Profitabilitas

Berdasarkan analisis didapat nilai koefisien regresi sebesar 0,177 dengan arah positif dan nilai signifikansi uji $\mathrm{t}$ variabel perputaran Persediaan sebesar 0,039. Karena nilai signifikansi uji $\mathrm{t}$ lebih kecil dari 0,05 maka hipotesis penelitian ke tiga diterima Jadi terdapat pengaruh positif yang signifikan variabel perputaran Persediaan terhadap profitabilitas.

\section{PEMBAHASAN}

\section{Pengaruh Perputaran kas terhadap Profitabilitas}

Berdasarkan kondisi pada supermarket di Timor-Leste terdapat berbagai kendala dalam suatu perusahaan tersebut terutama pada cuaca maupun suhu yang begitu panas di luar maupun dalam suatu perusahaan itu sendiri. maka terjadinya pembeli yang kurangnya berkunjung atau tidak berminat. Perputaran kas ditemukan berpengaruh tidak signifikan terhadap profitabilitas pada perusahaan supermarkat. Hal ini menunjukkan bahwa perputaran kas tidak mampu meningkatkan profitabilitas pada perusahaan tersebut penyebab perputaran kas tidak mampu meningkatkan profitabilitas pada perusahaan supermarket karena kas yang dimiliki perusahaan tidak dapat kelola secara optimal pada setiap 
periode, sehingga menyebabkan terlalu banyak kas yang ditahan dan tidak digunakan oleh karna itu tidak mampu meningkatkan profitabilitasnya.

\section{Pengaruh Perputaran Piutang terhadap Profitabilitas}

Perputaran piutang ditemukan berpengaruh yang signifikan terhadap profitabilitas pada perusahaan supermarket. Hal ini menunjukkan bahwa perputaran piutang telah berjalan baik dan lancar sehingga cepat berubah menjadi kas. semakin tinggi tingkat perputarannya maka semakin tinggi pula profitabilitas yang dicapai.

\section{Pengaruh Perputaran Persediaan terhadap Profitabilitas}

Perputaran persediaan ditemukan berpengaruh signifikan terhadap profitabilitas pada supermarkat. Hal ini menunjukkan bahwa perputaran persediaan mampu meningkatkan profitabilitas pada supermarket tersebut penyebab perputaran persediaan mampu meningkatkan profitabilitas pada supermarket karena persediaan yang dimiliki supermarket kelola dengan secara optimal dari setiap periode,sehingga dapat meningkatkan profitabilitas.

\section{SIMPULAN DAN SARAN}

Berdasarkan hasil penelitian dan pembahasan pada bab sebelumnya, maka secara umum dapat disimpulkan:

1) Perputaran kas ditemukan berpengaruh positif tetapi tidak signifikan terhadap profitabilitas. .

2) Perputaran piutang ditemukan berpengaruh positif terhadap profitabilitas.

3) Perputaran persediaan ditemukan berpengaruh positif terhadap profitabilitas. 


\section{REFERENSI}

Brigham, Eugene F dan Houston, Joel F. 2006. Dasar-Dasar Manajemen Keuangan. Jakarta : Penerbit Salemba Empat.

Ghozali, I. 2005. "Aplikasi Analisis Multivariate dengan Program SPSS" Edisi Ketiga. Semarang: BP Universitas Diponegoro.

Ghozali, Imam. 2006. Aplikasi Analisis Multivariate Dengan program SPSS. Semarang: Badan Penerbit Universitas Diponogoro.

Husnan, Suad dan Enny Pudjiastuti. 2004. Dasar-dasar Manajemen Keuangan. Edisi Keempat. Yogyakarta: UPP AMP YKPN

Kasmir. 2011. Analisis Laporan Keuangan.Edisi 1. Jakarta: Rajawali Pers.

Lazaridis and Tryfonidis. 2006. "The relationship between working capital management and profitability of listed companies in the Athens Stock Exchange". Journal of Business Finance \& Accounting, Vol. 19, No. 1, pp. $1-12$.

Manulang, Marihot dan Sinaga, Dearlina. 2005. pengantar Manajemen Keuangan. Edisi Pertama. Yogyakarta: Andi.

Munawir S. 2004. Analisa Laporan Keuangan. Edisi keempat. Liberty. Yogyakarta.

Putra, Lutfi Jaya. 2012. "Pengaruh Perputaran Modal Kerja Terhadap Profitabilitas (Studi Kasus : PT. Indofood Sukses Makmur Tbk.)”. Jurnal Ekonomi Gunadarma, Vol. 9. No. 1, hal. 1-10.

Raharjaputra, Hendra. 2009. Manajemen Keuangan dan Akuntansi. Jakarta: Salemba Empat.

Raheman, Abdul and Mohamed Nasr. 2007. "Working Capital Management And Profitability - Case Of Pakistani Firms". International Journal of Business Research Papers, Vol.3 No 1, pp. 279 - 300.

Rahma, Aulia. 2011. “Analisi Pengaruh Manajemen Modal Kerja Terhadap Profitabilitas Perusahaan". Jurnal Ekonomi.

Riyanto, Bambang. 2001. Dasar-dasar Pembelanjaan Perusahaan. Edisi Keempat Cetakan Keenam. Yogyakarta: BPFE.

Santoso, Rahmat Agus dan Mohammad Nur. 2008. "Pengaruh Perputaran Piutang dan Pengumpulan Piutang Terhadap Likuiditas Perusahaan Pada CV. Bumi Sarana Jaya Di Gresik”. Jurnal Logos, Vol. 6, No. 1, hal. 37 - 54.

Sartono, Agus. 2010. Manajemen Keuangan Teori dan Aplikasi. Edisi Keempat. Yogyakarta: BPFE. 
Matilde Amaral Canizio. Pengaruh Perputaran Kas, Perputaran Piutang, Perputaran...

Teruel, Pedro Juan Garcia and Pedro Martinez Solano. 2007. "Effect Of Working Capital Management On SME Profitability". International Journal of Managerial Finance, Vol. 3, No. 2, pp. 1-20.

Wiagustini, Ni luh Putu. 2010. Dasar - Dasar Manajemen Keuangan. Denpasar. Udayana University Press.

Wijaya, Anggita Langgeng. 2012. "Pengaruh Komponen Working Capital Terhadap Profitabilitas Perusahaan”. Jurnal Dinamika Akuntansi, Vol. 4, No. 1, hal. $20-26$. 